\title{
Intertidal ecosystems of the seas of the USSR
}

\author{
O. G. Kussakin \\ Laboratory of Chorology, Institute of Marine Biology; Vladivostok, USSR
}

\begin{abstract}
Composition and distribution of intertidal ecosystem of rocky and unconsolidated facies were quantitatively studicd from 1951 to 1975 in about 40 regions of the White, Barents, Bering, Okchotsk and Japan Seas. According to the degree of similarity (or to the degree of relationship), the investigated intertidal communities can be divided into the following 4 groups: (1) Uniform communities with identical forms as dominant species. A series of uniform communities constitutes a single association. (2) Parallel or vicarious communities with closely related vicarious forms as dominant species. A series of parallel communities constitutes a single formation. (3) Convergent or isomorphic communities with dominant species of the same, although not closely related life forms. A series of convergent communities constitutes a single formation type, or biome. (4) Anisomorphic, yet functionally analogous communities. Parallel communities of Fucus disticbus (northern Atlantic Ocean) and $F$. evanescens (northern Pacific Ocean), and uniform communities of $F$. evanescens from various biogeographic provinces (southern Kuriles and eastern Kamchatka) are used for demonstrating the structure of intertidal biocenoses. In parallel communities, vicarious species are shown to dominate in number of species and, especially, in biomass. In uniform communities, common species are found to be leading forms.
\end{abstract}

\section{INTRODUCTION}

Comparative ecological investigations of the intertidal zone enjoy special attention from Soviet hydrobiologists. These investigations were initiated in 1915 by Professor K. M. Derjugin in the Kola Fjord (Barents Sea) and then continued by E. F. Gurjanova, I. G. Zachs, P. V. Ushakov, N. N. Spassky, O. B. Mokievsky and others in various regions of the northern and far eastern seas of the USSR. The observations obtained have been reported in Russian in numerous papers (e.g. Zachs, 1927, 1929; Gurjanova et al., 1928-1930a, 1930b; Gurjanova \& Ushakov, 1928, 1929; Mokievsky, 1949, 1953, 1956, 1960; Ushakov, 1951; Spassky, 1961). Mokievsky and Gurjanova also briefly discussed the results of these studies in some articles published in English (Mokievsky, 1959; Gurjanova, 1961).

The works of Soviet authors are concerned with descriptions of flora and fauna, zonations of dominant species and communities, with variations in populations, patterns of vertical distribution under the influence of local factors, such as surf, water currents, etc., or factors, which control a broad geographical zonation. Moreover, Gurjanova, Zachs and Ushakov suggest in a series of their classical works a typology 
of the intertidal zone; the authors distinguished several bionomic types in the intertidal zone of the Murman coast. Their bionomic types correspond rather closely to the term "mode" adopted by P. de Beauchamp (1914).

Unfortunately, a variety of materials concerning the biology of the intertidal zone were collected by using different, sometimes inadequate methods, sometimes without quantitative study. When describing zonations, belt-forming communities were identified without listing all the macrobenthic species; only conspicuous or common forms were considered. This can be explained partly by the fact that the investigations of the intertidal zone were carried out either quite individually, or by very small groups of scientific enthusiasts. That is why the various contributions to our knowledge of the ecology of the intertidal zone are sometimes rather incomparable, especially regarding the data on composition, structure and succession of intertidal communities.

The present author began to study the intertidal zone in 1949, when working under the guidance of Professor E. F. Gurjanova on Shikotan Isle and continued in 1952 in Mezensky Bay (White Sea). Within the period of 1951-1957 I conducted investigations in the southern Kuriles. The author dealt with the specific composition and biographic structure of flora and fauna in the region mentioned above, as well as vertical zonation of communities and seasonal changes in the intertidal biota. I was not concerned with quantitative studies until 1958, when I began to deal more closely with the composition and structure of intertidal communities. At first, only macrobenthos was studied; meiofauna and microbenthos are under consideration since 1967. Moreover, intertidal sediments were studied at that time.

Thus, using the same quantitative and qualitative methods, we succeeded in the study of the intertidal zone of the eastern and western Murman coast, White Sea (Kussakin, 1963), and over 40 different regions of the far eastern seas of the USSR (Fig. 1).

In the regions studied, about 450 standard hydrobiological sections were made perpendicular to the coast, and about 4000 samples of macro-, micro- and meiobenthos were collected for quantitative and qualitative analyses. Simultaneously, we also studied the local sediments. We found and identified over 800 species of animals and about 200 species of plants in the macrobenthic material collected. The analysis of the meiobenthic material is still in progress.

\section{BIOGEOGRAPHICAL REGIONS}

Biogeographical analyses of flora and fauna have shown that the far eastern seas of the USSR, including part of the Pacific boreal region, can be subdivided into the following biogeographic subregions: the Ayne or North-Japan subregion of the low-boreal type and the South-Beringian subregion of the high-boreal type. The boundary between the two subregions lies in the northern part of the Tatar Strait, in the east of Terpenia Bay, Vries Strait and Katherina Strait (Okhotsk and Pacific coasts of the Kuriles, respectively). The high-boreal subregion extends northwards 
as far as the Bering Strait. Three provinces have been established within the SouthBeringian subregion: the Aleutian, Kurile and Lamutian (Fig. 1).

A determinant factor in this subdivision appears to be the summer temperature of coastal waters, which, in accordance with Hutchin's rule, limits the reproduction of warm-water species expanding north of their normal habitat and the survival of coldwater species spreading southwards. Consequently, the biogeographic boundary between the two subregions seems to occur where the mean monthly temperature of

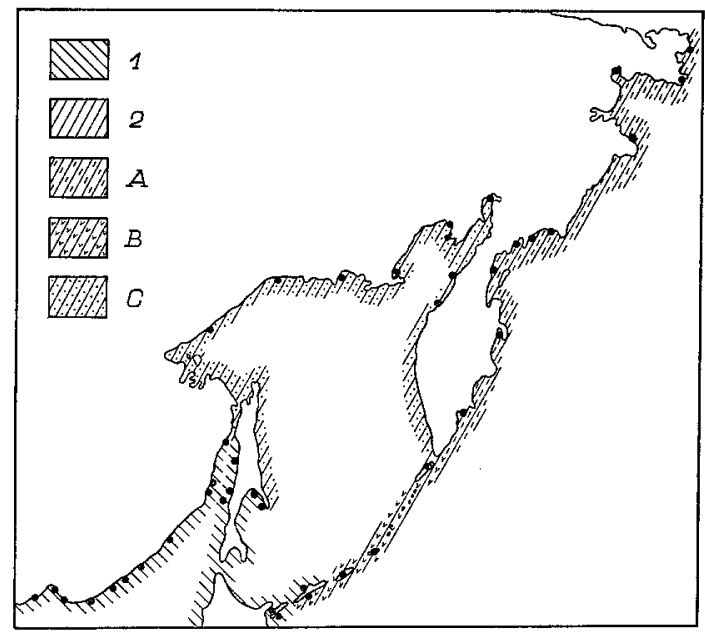

Fig. 1: Biogeographical subdivisions of the intertidal zone of the far Eastern seas of the USSR. 1 Ainy sub-region of boreal Pacific region, 2 South-Beringian sub-region of same region; A Aleutian province; B Kurile province; C Lamutian province. Intertidal zones investigated by Department of Hydrobiology and Ichthyology, Leningrad University (1951-1963) and by Laboratory of Chorology, Institute of Marine Biology are marked with circles

water is about $13^{\circ} \mathrm{C}$ for the warmest month, August (Kussakin, 1975, 1976). The regions with higher summer water temperatures are characterized by flora and fauna constituents of the low-boreal type, while the regions with lower summer water temperatures are characterized by those of high-boreal type.

Regular tidal fluctuation, patterns of wave action, ground properties, exposure to the effects of sunshine, ice and currents, daily and seasonal ranges in fluctuation of salinity, water and air temperatures should be considered the most significant in a variety of abiotic factors affecting the composition, distribution and vertical zonation of the intertidal communities. From the factors mentioned above, tidal fluctuation is believed to be the most dominant factor in determining the specificity of this peculiar zone, the intertidal zone.

It is precisely the correlation of durations of submergence and exposure in various parts of the intertidal zone that determines the vertical zonation of organisms and their communities in the zone; this vertical zonation is usually 
distinctly pronounced in all climatic zones. Therefore, Soviet explorers of the intertidal zone, basing their efforts on Vaillant's system (Vaillant, 1891) for regular, semidiurnal tides, widely use the principle of comparing the borders of horizons and storeys within the intertidal zone with the main tidal levels. In terms of this approach, the intertidal zone is subdivided into 3 horizons; the second, or the middle one being limited by mean high- and low-water neaps. The maximal highwater level or spring-tide is regarded as the upper border of the intertidal zone, the minimal low water level being, consequently, the lower border of the intertidal zone. Each horizon is subdivided into 2 storeys. Mean levels of high and low water spring tides are assumed to constitute the respective borders of the upper and lower horizons, the mean sea level determining the subdivision of the middle horizon into storeys. Moreover, Ushakov (1951) proved Vaillant's principle to be applicable also in an intertidal zone with irregular semidiurnal tides. In this case, the borders of storeys in the upper and lower horizons are considered to be mean levels of higher highwater and lower lowwater spring tides.

I applied Vaillant's system to irregular diurnal and irregular semidiurnal tides of the Kuriles Islands. It was found that diurnal tides are characterized not by spring or neap tides but by the respective tropical and equinoctial tide levels typical of this situation (Kussakin, 1958).

The scheme of vertical zonation of the intertidal zone, proposed by Vaillant, was modified by the author in terms of tide levels (Kussakin, 1961). A similar zonation was suggested by Gurjanova (1961), but she believes the number of storeys in the middle horizon to exceed two.

We consider the application of Vaillant's principle to be effective enough to obtain exact objective borders both of the intertidal zone as a whole and of its vertical subdivisions, horizons and storeys, irrespective of species, ground types, climatic conditions, wave action, etc.

Stephenson \& Stephenson's scheme (1972) and other similar systems, based on characteristics of the vertical distribution of typical communities seem to be applicable only for comparative ecological studies and, in addition, necessitate the zonation in accordance with Vaillant's principle.

Consequently, our approach requires us to change Stephenson's terminology somewhat. Since we regard the "zones" after Stephenson's terminology (mid-littoral zone, supra- and infra-littoral fringes) not as basic vertical divisions of an intertidal zone, but only as types of formations typical of rocky facies of the intertidal zone, we propose to term them "systems", or "systems of formations". Since the term "mid-littoral zone" (Stephenson's) can be easily mistaken for the middle littoral horizon (Vaillant's) it would be advisable to rename it "eulittoral system".

Comparing the borders of systems established by the Stephensons with the borders of horizons and storeys after Vaillant, we revealed that the supralittoral fringe along the sea coasts of the USSR, on shores with moderate or slight wave action (the 1 st bionomic type) coincides with the uppermost part of the intertidal zone or with the lower part of the supra-littoral zone; the infralittoral fringe coincides with the lowermost storey of the third horizon in the intertidal zone and the uppermost part of the infra-littoral zone. The main part of the intertidal zone 
is populated by eulittoral communities. The vertical zonation of communities corresponds then rather closely to the system of horizons and storeys established in terms of tide levels (Table 1).

Table 1

Vertical zonation of intertidal communities of a sheltered rocky coast on southern Kurile Islands. Bionomic Type 1

\begin{tabular}{|c|c|c|c|c|}
\hline \multicolumn{2}{|c|}{$\begin{array}{l}\text { Zones, horizons } \\
\text { and storeys }\end{array}$} & $\begin{array}{c}\text { South-eastern } \\
\text { coast of } \\
\text { Kunashir Island }\end{array}$ & $\begin{array}{l}\text { Shikotan } \\
\text { Island }\end{array}$ & $\begin{array}{l}\text { North-western } \\
\text { coast of } \\
\text { Iturup Island }\end{array}$ \\
\hline \multicolumn{2}{|c|}{ Supralittoral zone } & \multirow{2}{*}{$\begin{array}{l}\text { Littorina kurila } \\
\text { Ligia cinerascens }\end{array}$} & \multirow{2}{*}{ Littorina kurila } & \multirow{2}{*}{ Littorina kurila } \\
\hline \multirow{2}{*}{ 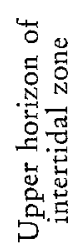 } & Upper & & & \\
\hline & $\begin{array}{l}\text { Lower } \\
\text { storey }\end{array}$ & Chthamalus dalli & $\begin{array}{l}\text { Chthamalus dalli- } \\
\text { Littorina kurila }\end{array}$ & $\begin{array}{l}\text { Gloiopeltis furcata- } \\
\text { Chthamalus dalli- } \\
\text { Littorina kurila }\end{array}$ \\
\hline \multirow{2}{*}{ 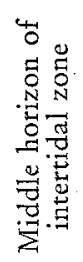 } & $\begin{array}{l}\text { Upper } \\
\text { storey }\end{array}$ & \multirow{2}{*}{$\begin{array}{l}\text { Pelvetia wrightii- } \\
\text { Polysipbonia } \\
\text { japonica } \\
\text { At lower part of belt: } \\
\text { Analipus } \\
\text { japonicus and } \\
\text { Corallina } \\
\text { pilulifera }\end{array}$} & Pelvetia wrigbtii & Pelvetia wrightii \\
\hline & $\begin{array}{l}\text { Lower } \\
\text { storey }\end{array}$ & & Fucus evanescens & Fucus evanescens \\
\hline \multirow{4}{*}{ 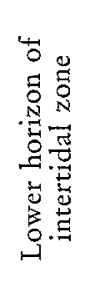 } & \multirow[t]{2}{*}{$\begin{array}{l}\text { Upper } \\
\text { storey }\end{array}$} & $\begin{array}{l}\text { Fucus evanescens, } \\
\text { Corallina, Analipus, } \\
\text { Rhodoglossum; } \\
\text { in patches }\end{array}$ & \multirow{3}{*}{$\begin{array}{l}\text { Corallina pilulifera, } \\
\text { Analipus japonicus } \\
\text { Halosaccion } \\
\text { glandiforme, } \\
\text { Rbodoglossun } \\
\text { japonicum }\end{array}$} & \multirow{2}{*}{$\begin{array}{l}\text { Analipus japonicus - } \\
\text { Rhodoglossum } \\
\text { japonicum }\end{array}$} \\
\hline & & \multirow{2}{*}{$\begin{array}{l}\text { Corallina } \\
\text { pilulifera - } \\
\text { Rbodoglossum } \\
\text { japonicum }\end{array}$} & & \\
\hline & \multirow{2}{*}{$\begin{array}{l}\text { Lower } \\
\text { storey }\end{array}$} & & & Rbodoglossum \\
\hline & & \multirow{2}{*}{$\begin{array}{l}\text { Lithothamnia, } \\
\text { Kjelmaniella gyrata, } \\
\text { Alaria praelonga; } \\
\text { rich fauna }\end{array}$} & $\begin{array}{l}\text { Kjelmaniella gyrata, } \\
\text { Corallina pilulifera }\end{array}$ & Corallina pilulifera \\
\hline \multicolumn{2}{|c|}{ Infralittoral zone } & & $\begin{array}{l}\text { Alaria praelonga- } \\
\text { Costaria costata }\end{array}$ & $\begin{array}{l}\text { Kjelmaniella gyrata- } \\
\text { Cystaseira crassipes }\end{array}$ \\
\hline
\end{tabular}

On the more wave exposed shores, communities shift upwards and occupy new habitats relative to the borders of zones, horizons and storeys; the degree of this displacement depends on the strength and duration of wave action (Table 2).

On the heavily wave exposed oceanic shores, the upward displacement of species becomes so great that the whole intertidal zone appears to be occupied by communities of the infra-littoral zone, whereas the intertidal communities inhabit the upper part of the shore above the intertidal zone. 
Table 2

Vertical zonation of intertidal communities on a wave exposed rocky coast of Kurile Islands. Bionomic Type 2

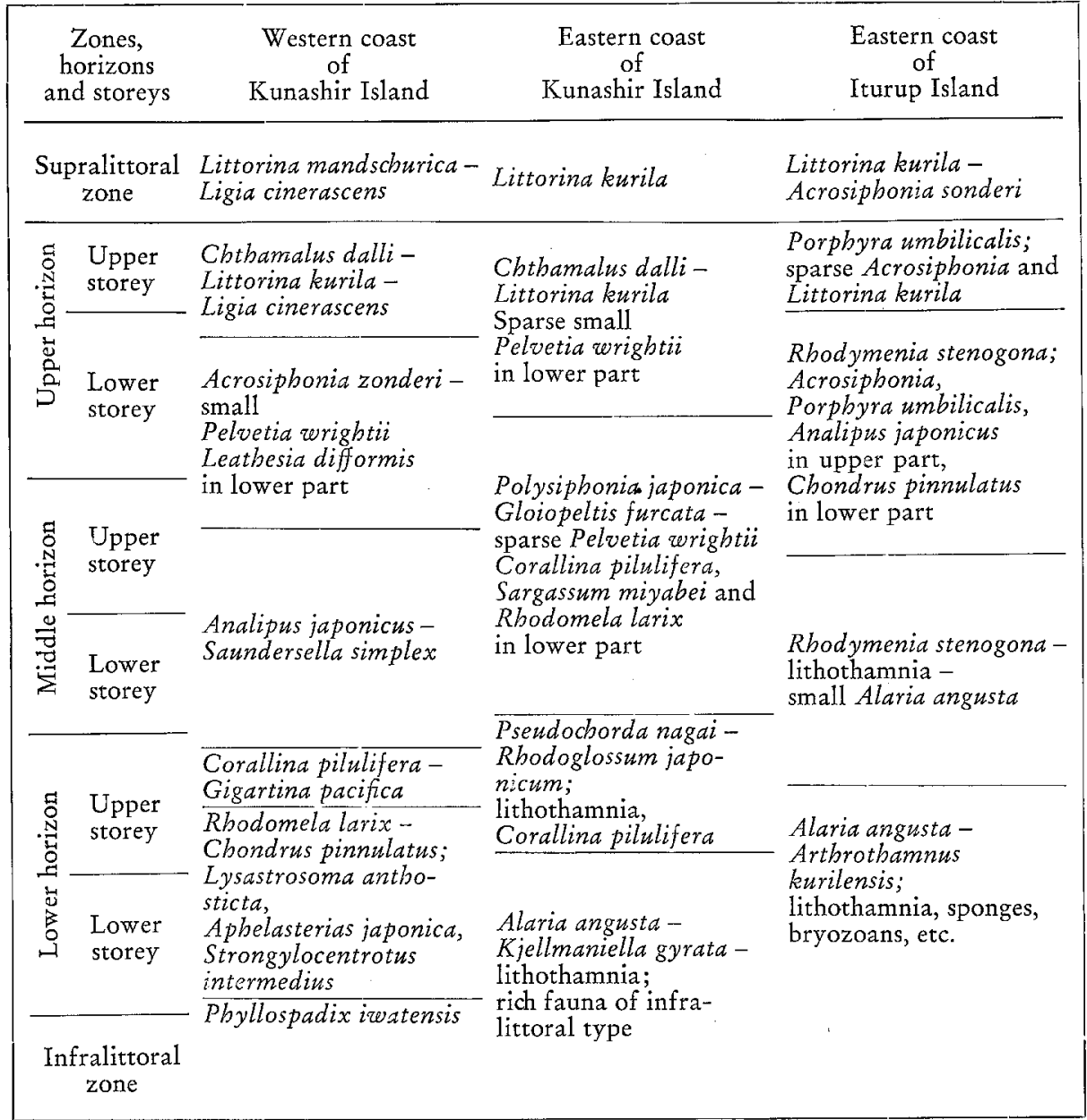

Thus, the approach of establishing objective borders of the whole zone, of its horizons and storeys in terms of tide levels affords us an opportunity to estimate any variations in the vertical zonation of organisms and their communities and to realize the causes of these variations for any definite case.

\section{BIONOMIC TYPES}

Based on principles proposed earlier by Gurjanova et al. (1930a, 1930b) for the establishment of bionomic types of the intertidal zone, we distinguished 
5 bionomic types along the coasts of northern and far eastern seas of the USSR. These types are as follows.

\section{First bionomic type}

The first bionomic type is characteristic of the moderately sheltered shore. For this type, a somewhat weakened wave action is typical. The water is well aerated, its salinity usually almost normal for sea-water but somewhat reduced in sites adjacent to estuaries. The first bionomic type comprises many inlets, the inner parts of some bays, as well as open seashores of complicated morphology and perfectly sheltered from strong wave action.

Most parts of the White Sea coast can be related to the first bionomic type; nevertheless, due to the low salinity of 25 to $26 \%$, the intertidal zone obtains there close similarity to an intertidal zone of the estuary type.

The first-bionomic intertidal zone is characterized by the greatest population density and diversity of resident communities. The vertical zonation of communities in the intertidal zone of the first bionomic type coincides well with horizons and storeys established in accordance with the main tidal levels.

On rocky facies, systems of formations can be easily recognized. The system of the supralittoral fringe is dominated by vicarious species of the genus Littorina: Littorina saxatilis on the Murman and the White Sea coasts; L. sitchana and L. kurila in the high-boreal Pacific Ocean. The last-mentioned species occurs intertidally also in the low-boreal regions, however, L. mandschurica and L. brevicula usually dominate there. The most typical algae are the green Urospora penicilliformis forming a kind of felt, Ulotrix pseudoflacca and others, and blue-green Calotbrix spp. In addition to littorinids, numerous amphipods are found: Gammarus oceanicus on the Murman and Chukchi coasts, and Anisogammarus locustoides as well as other species of the same genus in different sites of the far eastern seas.

The eulittoral system occupies most parts of the intertidal zone. In contrast to the supralittoral fringe, this system supports a remarkably more diverse population; however, only few formations occur here over greater distances of the coastal line. The boreal zone is dominated by formations of the barnacles Balanus and Chthamalus; by fucoids of the genera Fucus, Pelvetia and Ascopbyllum; and by bivalve mytilids.

The north Atlantic Ocean can be distinguished from the north Pacific Ocean by a significant abundance of fucoids. In the Atlantic Ocean, there are belt-forming associations of fucoids, including Fucus vesiculosus, $F$. distichus, F. serratus, Ascopbyllum nodosum; Pelvetia canaliculata is sometimes, abundantly found in tidepools even in high-boreal waters of the Murman coast. On the far eastern coasts, no Ascophyllum is recorded, Pelvetia wrightii populates exclusively low-boreal waters, and Fucus evanescens, the only representative of the genus Fucus, is of frequent occurrence. Sea limpets of the Patellidae are widely spread in the boreal intertidal zone of the Atlantic coasts, and a species of this family, Helcion pellucidus, reaches 
west Murman; on the Asiatic coast, the family never occurs even in low-boreal waters of the USSR.

Sea limpets of the family Acmaeidae (= Tecturidae) exhibit an example of contrary asymmetry: whereas a whole bouquet of species of the genera Acmaea, Collisella, Notoacmea, Problacmaea and Testudinalia populate the fare eastern seas, only the species Testudinalia tessellata occurs in most parts of the boreal European coast. The Atlantic form Chthamalus stellatus only reaches southern England; northwards it completely disappears from the fauna and is replaced by Balanus balanoides.

Its Pacific analogue, Chtbamalus dalli, forms a belt extending at least as far as Olyutorski Bay (Bering Sea). Still, the species usually constitutes pure colonies only in the low-boreal regions. In the high-boreal regions, it forms mixed associations with Balanus balanoides in the Okhotsk Sea and with $B$. crenatus on the eastern Kamchatka coast and in the Bering Sea.

The lower part of the eulittoral system is usually dominated by small- or moderate-sized algae, mostly red algae or Rhodophyta. The red algae Halosaccion ramentaceum, Rhodymenia palmata, Cystoclonium purpureum are of frequent occurrence on the Murman and the White Sea coasts; in addition, Rbodomela lycopodioides and Corallina officinalis are common on the Murman coast.

In the boreal zone of the northwestern Pacific Ocean, very similar communities are found on the lower part of the eulittoral system, their species composition being remarkably more diverse. Thus, a rather poorly populated intertidal zone in the Bay of Providence contains the community of Halosaccion glandiforme accompanied by H. compressum, Pylaiella littoralis and Rhizoclonium riparium, and Halosaccion compressum at somewhat lower levels. On eastern Kamchatka, the formation of loweulittoral red algae is represented mainly by the communities of Rhodomela larix Mytilus edulis, Corallina pilulifera - M. edulis, Halosaccion glandiforme - Collisella cassis, Rhodymenia stenogona - Collisella cassis and Gigartina pacifica. On the northern and middle Kurile Islands, the communities of red algae, namely Rhodymenia stenogona, Rbodomela larix, Rbodoglossum japonicum, Iridaea cornucopiae and Ptilota asplenioides are most typical of the lower part of the eulittoral system. Ptilota asplenioides of the middle Kurile Islands is abundantly overgrown by the bivalve Vilasina vernicosa. Hermit crabs and sea limpets are absent in the fauna of the coldest Middle Kuriles (water temperature at the shore: 3.5 to $8^{\circ} \mathrm{C}$ in August).

The Okhotsk coast of the mainland is most abundantly populated by Mytilus edulis, extending below into the infralittoral zone; the lower part of the eulittoral system is occupied by various algae with a mosaic type of distribution: communities of the red algae Halosaccion ramentaceum, $H$. microsporum, Rhodymenia stenogona, Rhodomela tenuissima, Chondrus crispus, Tichocarpus crinitus, Corallina pilulifera, the brown algae Chordaria flagelliformis and Scytosipbon lomentarius, and the green alga Ulva fenestrata.

The intertidal zone of the southern Kuriles, southern Sakhalin, of northern sites of the Sea of Japan and northwards to the Nevelskoj Strait is of the low-boreal type. The general appearance of the eulittoral communities there remains very similar to those of the high-boreal zone, although in the upper eulittoral part there 
appear communities of Pelvetia wrightii. The communities of some relatively warmwater algae, including Laurencia spp., Chondrus yendoi, Leathesia difformis, Colpomenia sinuosa and others are found in the lower part, below the Fucus evanescens belt. Some high-boreal species, such as Littorina sitchana, Nucela lima, Margarites belicina, Pagurus hirsutiusculus, Lacuna reflexa and Epheria porrecta, gradually disappear from the fauna of these regions, and some vicarious low-boreal species, such as Littorina mandscburica, Nucella beyseana, Margarites pilsbryi, Pagurus brachiomastus, Lacuna uchidai, and Epheria turrita take their place. Moreover, a general enrichment of faunal composition is observed due to the additional occurrence of some non-vicarious forms; these species include the decapods Hemigrapsus, Eriocheir, Cancer, Pugettia, Pachycheles, a few isopod genera of the family Sphaeromatidae (Dynamenella, Dynoides, Holotelson), oysters and others.

The infralittoral fringe system of boreal waters is mainly characterized by an abundance of laminarians extending into the infralittoral zone. The communities of Laminaria saccharina and $L$. digitata are common for the high-boreal intertidal zone of European seas, Fucus serratus replace them in sheltered areas with weaker surf. Algae common in the lower part of the eulittoral system play an important role as "undergrowth". In the northern Pacific Ocean, no fucoids are found in the infralittoral fringe, but laminarian communities are usually well developed. In Cross Bay, Laminaria bongardiana appears and extends southwards along the coasts of eastern Kamchatka, and northern and middle Kurile Islands. Lessonia laminariodes and Laminaria gurjanovae are typical of the mainland coast of the Okhotsk Sea.

In the infralittoral fringe of the low-boreal southern Kuriles, besides the Laminariaceans Kjellmaniella gyrata and Costaria costata, dense sargasso weeds Cystoseira crassipes and less plentiful Sargassum kjellmanianum and S. thunbergi are also found. On the southern Sakhalin, Cystoseira crassipes, Sargassum pallidum, Laminaria cicharioides and L. japonica are common. Both low-boreal areas mentioned above also contain abundant populations of the seagrass Pbyllospadix iwatensis; no analogues of this seagrass have been found thus far in the high-boreal subzones of the Atlantic and the northwestern Pacific Oceans. On the northern mainland coast of the Sea of Japan, laminarians extend only locally into the infralittoral fringe. Pbyllospadix and sargasso weeds are typical only of the upper part of the infralittoral zone, whereas the infralittoral fringe is populated predominantly by diverse seaweeds, mainly red and some brown algae; among the latter, Coccophora langsdorffii is typical.

The same red algae constitute a significant part of the "undergrowth" in other areas of the northwestern Pacific Ocean, where laminarians are dominant. Thus, the red algae Tichocarpus crinitus, Chondrus pinnulatus, Gigartina pacifica, Halosaccion glandiforme, Odonthalia spp., Polysipbonia spp., Ptilota asplenioides and P. flicina are most common. In addition, Porphyra tasa, Halosaccion ramentaceum, $H$. firmum are frequently found in the high-boreal subzone, and Laurencia spp., Bossiella cretacea, Glateloupia spp. are typical of the low-boreal subzone. Everywhere in the northern Pacific Ocean, within the infralittoral fringe, lithothamnia appear to be more typical of the infralittoral zone.

The infralittoral fringe harbours the most diversified fauna. In addition to a 
number of animals inhabiting the eulittoral zone, numerous echinoderms appear, mainly sea urchins Strongylocentrotus droebachiensis in the Barents Sea, S. aff. droebacbiensis and $S$. polyacanthus in the high-boreal intertidal zone of the Pacific, and $S$. intermedius in the low-boreal intertidal zone; sea stars Asterias rubens in the Barents and the White seas, Leptasterias camtschatica and L. alascensis asiatica in the high-boreal subzone of the Pacific, and L. similispinis, Apbelasterias japonica, Lethasterias fusca as well as Lysastrosoma anthosticta in the low-boreal subzone of the Pacific Ocean. Decapods Telmessus cheiragonus, Hapalogaster grebnitzkii, Dermaturus mandti and young Paralithodes brevipes, as well as the giant chiton Cryptochiton stelleri are also widespead in the far eastern seas of the USSR. On the Okhotsk Sea coast, the large chitons Amicula pallasii and $A$. vestita, and in the low-boreal waters, Ischnocbiton bakodadensis are also common.

Non-consolidated facies within the intertidal zone of the first bionomic type are also rather richly populated. This is particularly true with regard to the low horizon of the intertidal zone occupied by dense populations of seagrasses: Zostera marina in the White Sea, Z. marina and Z. japonica in the far eastern seas.

Somewhat above, the vegetation is usually sparse and the intertidal zone is mostly dominated by the infauna. In the White and Barents seas, Macoma baltica, Mya arenaria, $M$. truncata, Arenicola marina; and small polychaets, such as $S$ pio filicornis, Fabricia sabella, Capitella capitata, as well as some others are the most common species. The high-boreal sedimentary shores of the far eastern seas are populated by the same polychaetes, but $A$. marina forms a separate subspecies, $A$. m. schantarica, replaced locally by Abarenicola pacifica. In addition to Macoma balthica, these sandy flats are also inhabited by $M$. lama, Mya priapus, $M$. psendoarenaria and $M$. japonica (instead of the Atlantic species Mya arenaria and $M$. truncata); the Okhotsk coast of the mainland also supports settlements of the bivalve Liocyma fuctuosa. In the low-boreal areas, the bivalves Macoma incongrua, Venerupis japonica, Protothaca euglypta, Spisula sachalinensis and Peronidia venulosa are found, as well as Arenicola claparedi, Mya japonica and Macoma balthica and the crab Upogebia major.

The populations of the upper half of the intertidal zone are remarkably reduced: macrophytes are usually lacking, and the macrofauna is represented only by amphipods of the family Gammaridae, or by Talitridae (in the far eastern seas).

In the following sections, I review the remaining bionomic types in most general terms.

\section{Second bionomic type}

The second bionomic type is characteristic of the open sea shore. Strong wave action is typical. The salinity is high, almost as high as in sea areas. Aeration is good and frequently results in oxygen supersaturation. The damaging scouring effect of surf dominates over the favourable aeration and wetting effects of the surf.

The intertidal zone of the second bionomic type is populated mainly by communities typical of the first bionomic type; however, these communities shift remarkably upwards (Table 2). Some communities, for instance the community of Ascophyllum nodosum in northern Atlantic Ocean, disappear completely. 
Only reduced fucoids vegetation is found in the eulittoral system, whereas the Mytilidae are abundant. On the Kurile Islands, eastern Kamchatka and the Komandorskye Islands, large barnacles (Balanus cariosus) are plentiful. In the upper half of the eulittoral system of the Murman coast and, locally, on the far eastern shores, the Porpbyra umbilicalis community is of frequent occurrence. Communities of Gloiopeltis furcata, Analipus japonica, Blindingia minima and Acrosipbonia sonderi colonize some coastal areas of the Okhotsk and Japan seas and of the Kuriles. The Beringian coast of Chukchi Peninsula supports a prominent community of Porphyra pseudolinearis - Urospora penicilliformis - Bacillariophyta and Scytosiphon dotyi Petalonia fascia - Pylaiella litoralis. The communities of the infralittoral fringe are generally characterized by a reduction or complete disappearance of Sargassaceae and many Laminariaceae; these are replaced by Alariaceae and other genera of Laminariaceae, as well as by mussels and lithothamnia.

Laminariales are intertidally widespread: Alaria esculenta dominate on the Murman coast, $A$. angusta colonize the eastern coast of Kamchatka, and the northern and middle Kuriles support, in addition to the last-named species, also Laminaria longipes, Cymathaere triplicata and, more rarely, Alaria praelonga, Artbrotbamnus bifidus and A. kurilensis. Laminarians and Mytilus edulis are sparse in the low-boreal infralittoral fringe. On the southern Kurile Islands, Laminariales are represented by locally occurring communities of Arthrothamnus bifidus and Alaria prealonga, on southern Sakhalin by $A$. marginata. In the north-western part of the Sea of Japan, these seaweeds are not found in the infralittoral fringe.

In the three low-boreal areas mentioned above, Cystoseira crassipes is common, and at the boundary with the eulittoral system, Corallina pilulifera is abundantly overgrown by Leatbesia difformis.

Unconsolidated facies are usually represented by sand, more rarely by gravelsandy or pebble-sandy sediment. On the Bering coast of the Chukchi Peninsula, broken-stone grounds occur widely. All the beaches there are poorly populated. As a rule, macrophytes are absent. Almost along the whole far eastern coast, amphipods of the family Talitridae, common above the wash belt of the surf zone, move up and down with the tides, shifting downwards, into the intertidal zone with the receding tide. The characteristic feature of the wash belt of the surf zone on sandy beaches of southern Prymorye, southern Kuriles and northwards as far as Chukchi Peninsula is the mysid Archaeomysis grebnitzkii. Besides this species, only scattered individuals of Haustorius washingtonianus and Gammaridae occur intertidally in the high-boreal areas, but meiobenthic Turbellaria, Oligochaeta and Nematoda are common.

In low-boreal areas, in addition to the species mentioned above, polychaetes Nephthys longosetosa, Glycera tridactyla, Euzonus arcticus and Polydora californica, as well as bivalves Nuttalia olivacea are usually found. Isopods Excirolana japonica have only been sampled in the extreme south of Kunashir Island. 


\section{Third bionomic type}

The third bionomic type occurs on open oceanic shore. The coast is subject to heavy and perpetual wave action, producing an extensive washing of the intertidal zone, which remains wet even during low tide. Due to the strong damaging effect of surf, the populations present are much reduced: however, a few wave-tolerant species, not challenged by competitors, thrive extensively in nearly the whole intertidal zone.

The intertidal zone of the third bionomic type distinctly differs in its appearance from that of the second bionomic type. The belt-forming communities shift vertically upwards usually more than $0.5-1.0 \mathrm{~m}$. This is much more than on sheltered shores. Fucoids and many laminarians typical of rocky facies, are rare here or absent. Corallina pilulifera is of restricted occurrence in cracks and holes of the rocky substratum. Analipus japonicus exists in general, as a crust form.

Wave-tolerant species, such as the seaweeds Gloiopeltis furcata, Polysiphonia spp., Pterosiphonia bipinnata, Neodilsea yendoana and the animals Balanus cariosus, Mytilus edulis, sabellids and compound ascidians are dominant. Communities of the infralittoral fringe spread into upper levels and occupy the whole or nearly the whole intertidal zone. On Iturup Island, the most successful algae are Alaria angusta and Arthrothamnus kurilensis. Animals are very scarce and inhabit, except for some hydroids, mainly cracks and holes. The eulittoral communities occupy the wash zone above the upper tide level (Table 3).

\section{Fourth bionomictype}

The fourth bionomic type is characteristic of lagoons but including sheltered bays and inlets. A typical feature of this zone is the absence of surf. The salinity is more or less reduced in cold and temperature regions, but exceeds that of the open sea in areas with a warm, arid climate. Unconsolidated facies, such as muddy sands, alevrits and some others, are typical of this bionomic type. The intertidal zone of the lagoon is well represented along the coasts of the far eastern seas. High-boreal lagoons are rather poorly populated. In lagoons of the Anadyr Bay, seagrasses are absent, the flora is represented by blue-green and brown algae, namely Pylaiella litoralis and Stictyosiphon tortilis, and diatoms - all in equal amounts $\left(120 \mathrm{~g} \mathrm{~m}^{-2}\right.$ on the average).

Animals are even scarcer (average biomass: 20 to $30 \mathrm{~g} \mathrm{~m}^{-2}$ ), amphipods Anisogammarus barbatus and Gammarus setosus being more abundant. The community of Zostera marina - Littorina squalida starts appearing in lagoons beginning at the Olyutorski Bay.

Lagoons and sheltered inlets of the low-boreal subregions are much more richly populated. In spite of ice cover during several winter months, a maximum concentration of warmwater species, both subtropical and subtropic-boreal, is found at these very locations. According to the evidence reported by many authors (e.g. Appellöff, 1912; Orton, 1920; Allee, 1923), this fact is associated with the higher summer temperatures of the water in such areas, in contrast to the colder open seashore. The infralittoral fringe here contains a broad belt of seagrass Zostera japonica, with the 
Table 3

Vertical zonation of intertidal communities on a heavily wave-exposed oceanic rocky coast (southeastern coast of Iturup Island). Bionomic Type 3

\begin{tabular}{|c|c|c|c|c|c|}
\hline $\begin{array}{l}\text { Level } \\
\text { above } \\
\text { zero } \\
\text { depth } \\
\text { (m) }\end{array}$ & $\begin{array}{l}\text { Benthal } \\
\text { zone }\end{array}$ & \multicolumn{2}{|c|}{$\begin{array}{l}\text { (A) Heavily exposed } \\
\text { fore reef }\end{array}$} & \multicolumn{2}{|c|}{$\begin{array}{l}\text { (B) Slightly sheltered } \\
\text { fore reef }\end{array}$} \\
\hline \multirow[t]{2}{*}{4} & \multirow{3}{*}{$\begin{array}{l}\text { Supra- } \\
\text { littoral } \\
\text { zone }\end{array}$} & $\begin{array}{l}\text { Rare } \\
\text { spraying } \\
\text { in } \\
\text { low water }\end{array}$ & $\begin{array}{l}\text { Chthamalus dalli- } \\
\text { Littorina kurila- } \\
\text { Gloiopeltis furcata }\end{array}$ & \multirow{3}{*}{$\begin{array}{l}\text { Rare } \\
\text { spraying } \\
\text { in } \\
\text { low water }\end{array}$} & $\begin{array}{l}\text { Poor } \\
\text { supralittoral } \\
\text { fauna }\end{array}$ \\
\hline & & $\begin{array}{l}\text { Irregular } \\
\text { spraying } \\
\text { in } \\
\text { low water }\end{array}$ & $\begin{array}{l}\text { Polysiphonia japonica- } \\
\text { Rbodomela tenuissima }\end{array}$ & & Chtbamalus dalli- \\
\hline & & \multirow[t]{5}{*}{$\begin{array}{l}\text { Regular } \\
\text { spraying } \\
\text { in } \\
\text { low water }\end{array}$} & \multirow{5}{*}{$\begin{array}{l}\text { Alaria angusta, } \\
\text { lithothamnia, } \\
\text { hydroids, } \\
\text { compound ascidians, } \\
\text { amphipods, } \\
\text { Dermaturus mandti, } \\
\text { Mytilus edulis, etc. }\end{array}$} & & Littorina kurila \\
\hline 2 & $\begin{array}{l}\text { Inter- } \\
\text { tidal } \\
\text { zone }\end{array}$ & & & \multirow{2}{*}{$\begin{array}{l}\text { Irregular } \\
\text { spraying } \\
\text { in } \\
\text { low water }\end{array}$} & $\begin{array}{l}\text { Balanus cariosus- } \\
\text { Cbtbamalus dalli }\end{array}$ \\
\hline 1 & & & & & $\begin{array}{l}\text { Balanus cariosus- } \\
\text { Pterosiphonia bipinnata }\end{array}$ \\
\hline 0 & & & & $\begin{array}{l}\text { Regular } \\
\text { spraying } \\
\text { in } \\
\text { low water }\end{array}$ & $\begin{array}{l}\text { Alaria angusta- } \\
\text { Arthrothamnus kurilen- } \\
\text { sis; fauna and flora of } \\
\text { infralittoral type }\end{array}$ \\
\hline Infr & $\begin{array}{l}\text { calittoral } \\
\text { zone }\end{array}$ & & & $\begin{array}{l}\text { Infra- } \\
\text { littoral } \\
\text { zone }\end{array}$ & \\
\hline
\end{tabular}

leaves densely overgrown by Colpomenia sinuosa, or Punctaria plantaguinea and Eudesme virescens (on dead leaves). The dominate fauna here is Batillaria cumingii, Musculus senbousia, Pandalus latirostris, Crangon septemspinosa, var. propingua. Other common animals are Macoma incongrua, Neptunea artbritica, Littorina brevicula, L. mandsburica, Tritia fratercula, $T$. acutidentata, as well as various polychaetes and amphipods. Leaves of Zostera are populated, in addition to Littorina squalida, by Homalopoma sangarense and Williamia oblongata.

The eulittoral system is presented by muddy sand with numerous (1000 or more $\mathrm{m}^{-2}$ ) Batillaria cumingii and patches of Zostera japonica. The infauna includes Arenicola claparedii and some other polychaetes.

The supralittoral fringe contains a varied assortment of animals: amphipods Orchestoidea brito, isopods Detonella sachalina, as well as insects and mites. 


\section{Fifth bionomic type}

The fifth bionomic type is characteristic of estuaries, with slight wave action or a complete absence of surf. The salinity is more or less reduced and usually varies significantly in response to tidal phase. The typical feature of both, lagoons and estuaries, is prevalence of unconsolidated facies: mainly various sands. However, the alevrit content of the sandy grounds is usually lower in estuaries. In addition to typical estuaries, inner parts of some inlets with brackish water in the Barents and the far eastern seas, as well as (presumably) some diluted bays of the White Sea, can be referred to this bionomic type.

The high-boreal intertidal zone of the White Sea and a part of the far eastern seas exhibit a conspicuous community development of Mytilus edulis. In estuaries, this bivalve forms banks on muddy flats, not on rocks. The community of Mesidoted entomon - Amphipoda is common on finer alevrit grounds. Frequently, the upper part of the intertidal zone is occupied by a vegetation of salt-tolerant flowering plants: Salicornia berbacea, Plantago maritima, Aster tripolium, Triglochin maritima, Juncus gerardi, Atriplex littoralis, and others.

The low-boreal intertidal zone of the estuary type is dominated by polychaetes Nereis japonica reaching 5000 holes $\mathrm{m}^{-2}$, gammarid amphipods and isopod species of the genus Gnorimosphaeroma. Gastropod molluscs Cecina manshurica and Assimineidae are common for the upper half of the intertidal zone of this type.

I do not deal here with tide-pools, previously regarded as the sixth bionomic type; these can better be discussed separately.

\section{COMMUNITIES}

Intertidal investigations, especially on rocky facies, usually reveal a diversity of belt-forming communities. Thus, for instance, we found at least 27 local belt-forming communities, sharply different in their appearance and their dominant species, on rocky shores of the open Kronotsky Bay (eastern Kamchatka), which is not particularly distinguished either in number of bionomic types or in variety of species.

Considering this great variability of the intertidal communities under the combined influence of local factors, and imagining how different the shores all around the world may be, it would be easy to speculate that the intertidal biota is nearly infinitely diverse. However, this is far from being true and contradicts the facts: the communities forming in all the geographical areas under bionomically analogous conditions, are with an amazing regularity uniform or at least physiognomically similar. They contain a limited set of species, dominant ones in particular, which appear to be either the same, or vicarious, or morphologically similar. Consequently, the whole diversity of intertidal communities, astonishing at the first sight, appears, after detailed study, to be composed of a few regularly repeated series of rather similar communities, i.e. formations (Dellow, 1950; Feldmann, 1951).

According to the degree of similarity (or relationship) all intertidal communities can be divided into the following 4 groups: 


\section{Uniform communities}

Uniform communities inhabit similar biotopes usually within the same biogeographical province or region (rarely within the same climatic zone) and are dominated by the same species. A series of uniform communities compose an association. It is essential to note that, due to local variations of environmental conditions, uniform communities can differ in their species composition both in distant and in adjacent areas. In particular cases, uniform communities of one association may or may not have species in common, except dominants themselves and some species typical of

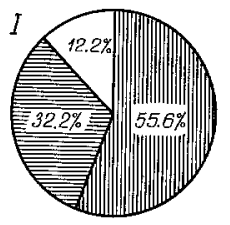

$A$
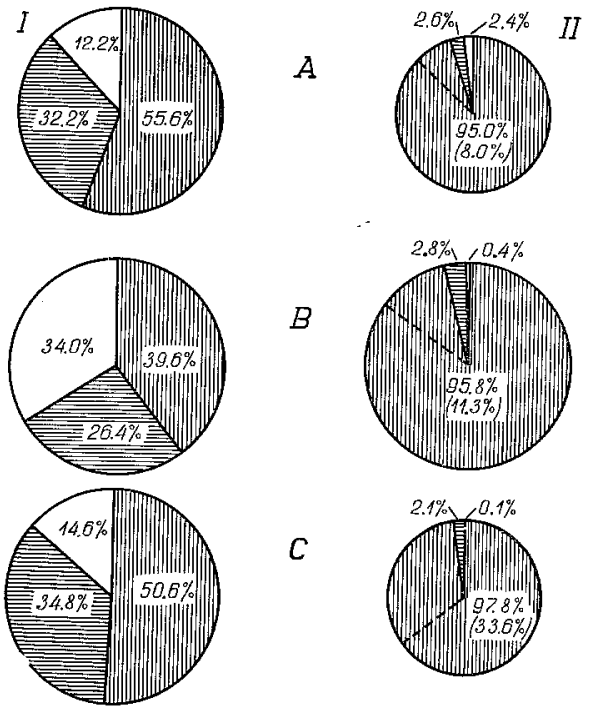

$C$
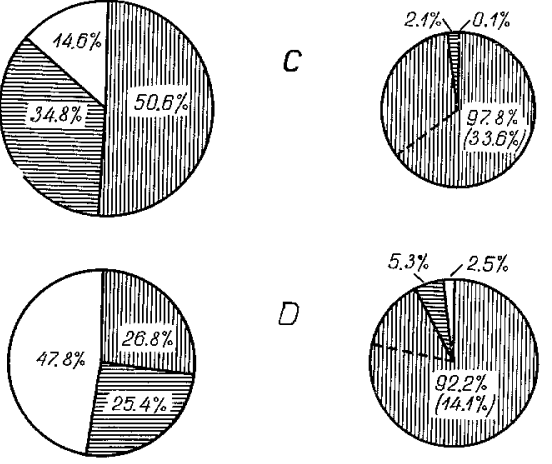

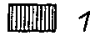

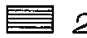

3

Fig. 2: Species structure in uniform communities (Fucus evanescens association in different areas of northwestern Pacific Ocean). Areas are proportional to number of species in investigated community (I) and to the macrobenthic mean biomass calculated per $\mathrm{m}^{2}$ of bottom surface (II). Relative biomass value of prevailing group species, except the dominant, placed in brackets and separated by a broken line. A South Kurile Island: number of macrobenthic species -90 , mean biomass $-4800 \mathrm{~g} \mathrm{~m}^{-2}$. B North Kurile Islands: number of macrobenthic species - 91, mean biomass - $8950 \mathrm{~g} \mathrm{~m}^{-2}$. C Eastern Kamchatka coast: number of macrobenthic species 89 , mean biomass - $4500 \mathrm{~g} \mathrm{~m}^{-2}$. D The Gulf of Anadyr: number of macrobenthic species -71 , mean biomass $-5600 \mathrm{~g} \mathrm{~m}^{-2}$. (A exemplifies a low-boreal area, B-D high boreal areas). 1 Widely distributed boreal species common to high-and low-boreal waters, 2 vicarious species, 3 non-vicarious species, distributed exclusively in low-or high-boreal waters 
the whole intertidal zone of this region. Thus, in the infralittoral fringe of the northwestern coast of the Iturup (sland (Kurile Islands), rocky and stony facies are typically occupied by the Cystoseira crassipes association. It was, however, found, that only 2 species of algae (from 17 species found in association) and only 4 species of animals (from 45 found in association) were common for rock and stone communities (Kussakin et al., 1974). Nevertheless, the communities belonging to the same association seem to be very similar in their appearance due to ecological and geographical vicariation of species. It is worth noting that the predominance of common species is always more pronounced in their biomass than in their total number of species. This is exemplified by the species composition of the eulittoral association of Fucus evanescens from the Anadyr Bay, eastern Kamchatka, Northern and Southern Kuriles Islands (Fig. 2), which is most typical of the northern Pacific Ocean. In spite of the fact that the first three areas belong to the high-boreal subzone of the boreal zone, and the last one to the low-boreal subzone of the same zone, the most numerous within the respective uniform communities are the same species equally widespread in both subzones. These species seem to become less significant only in Chukchi Peninsula with its nearly subarctic environment. The number of vicarious forms ranges here from 25 to $35 \%$ of the total number of species present, whereas the number of species occurring exclusively in the high- or the low-boreal intertidal zone and possessing no vicariants in other areas is estimated to vary from 12 to $48 \%$.

When considering these two groups (vicarious and different nonvicarious) of species in terms of biomass, they both appear to be less significant as their biomass averages just 3 to $8 \%$ of the total biomass.

Part of the common species appear to be more important, as their biomass (even excluding the dominant species) makes up 8 to $40 \%$ of the total biomass. It should be noted that three areas out of the four in question support practically equal numbers of species in the association of Fucus evanescens (90, 91 and 89). Just in the extreme north of the boreal zone, the number of species in the association is reduced to 71 which should be considered a minor decrease when we take into account the poor intertidal biota of Chukchi Peninsula. This evidence does not contradict the wellknown fact that, in the boreal zone, the number of species increases in a southerly direction. The northward reduction of the intertidal biota can be explained mainly by a gradual disappearance of less eurybiont species, adapted only to one or a few communities. The remaining more eurybiont species can be constituents of quite different communities within the same facies. Thus, whereas the $F$. evanescens association of the southern Kuriles contains only $15 \%$ of the total number of macrobenthic species found there, this number increases steadily northwards (19\% in the middle and northern Kuriles, $32 \%$ in eastern Kamchatka, and 39\% in Anadyr Bay).

On the whole, we can conclude that, in spite of remarkable local variations (sometimes sharp difference can be observed even between two sides of one and the same rock), the species composition of uniform communities tends to remain constant throughout a vast area, at least with regard to its most prominent species. 


\section{Parallelor vicarious communities}

Groups of organisms inhabiting similar biotopes in various zones, biogeographical regions and provinces, and dominated by closely related species - usually species of the same genus, rarely of various genera within the same family, and more rarely of various genera within the same family, and most rarely by species of various families within a superfamily - should be considered as parallel (Thorson, 1957, 1958), or

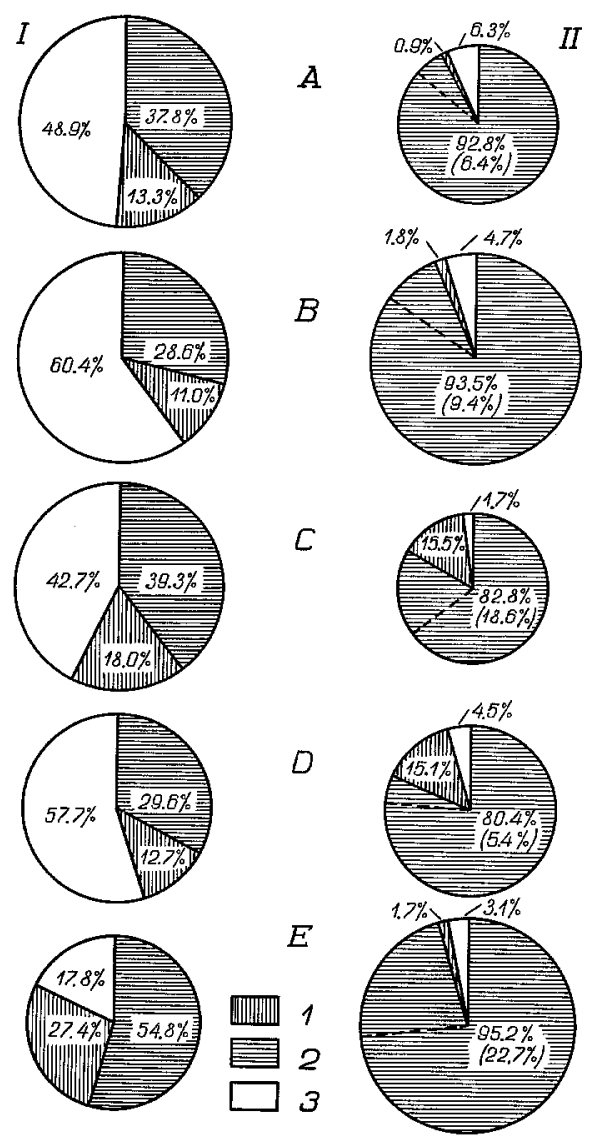

Fig. 3: Comparison of species structure in parallel communities of Fucus evanescens (A-D) in northwestern Pacific Ocean. F. distichus (E) from Murman coast (Barents Sea). A South Kurile Island: number of macrobenthic species -90 , mean biomass $-4800 \mathrm{~g} \mathrm{~m}^{-2}$. B North Kurile Islands: number of macrobenthic species -91 , mean biomass $-8950 \mathrm{~g} \mathrm{~m}^{-2}$. C Eastern Kamchatka coast: number of macrobenthic species -89 , mean biomass $-4500 \mathrm{~g} \mathrm{~m}^{-2}$. D The Gulf of Anadyr: number of macrobenthic species -71 , mean biomass $-5600 \mathrm{~g} \mathrm{~m}^{-2}$. (A exemplifies a low-boreal area, B-D high boreal areas). 1 Widely distributed boreal species common to high- and low-boreal waters, 2 vicarious species, 3 non-vicarious species, distributed exclusively in low- or high-boreal waters. E: Island of Murman coast: number of macrobenthic species - 62, mean biomass $9130 \mathrm{~g} \mathrm{~m}^{-2} .1$ Species common to Pacific-Ocean and Barents-Sea communities; 2 vicarious species; 3 non-vicarious species 
vicarious communities. A series of associations composed of such communities can be regarded as constituents of one formation.

Parallel communities frequently dominate in various biogeographic regions or subregions within the same climatic zone. Thus, I would like to exemplify the following vicarious associations of the European and the far eastern seas belonging to different regions of the boreal zone:

European seas:
Chthamalus stellatus
Pelvetia canaliculata
Littorina obtusata
Testudinalia tessellata
Gammarus oceanicus -
$\quad$ Littorina saxatilis
Halosaccion ramentaceum
Rhodymenia palmata
Alaria esculenta-
$\quad$ Laminaria digitata

European seas:

Chthamalus stellatus

Pelvetia canaliculata

Littorina obtusata

Testudinalia tessellata

Littorina saxatilis

Halosaccion ramentaceum

Rhodymenia palmata

Laminaria digitata
Far eastern seas:

C. dalli

$P$. wrightii

L. kurila

Collisella cassis

Anisogammarus locustoides Littorina sitchana

H. glandiforme

$R h$. stenogona

$A$. angusta - L. bongardiana

Even more widespread intertidally are vicarious communities of soft grounds, where bivalve mollusks of the families Veneridae, Cardiidae, Mactridae, Tellinidae, Psammobiidae, Solenidae and Myidae usually dominate.

Unlike uniform communities, parallel communities have vicarious species as the most significant component with regard to biomass (the biomass of these species averages 80 to $95 \%$ ), although vicarious species are not so prominent, they make up 29 to $55 \%$ of the total number (Fig. 3).

Only Mytilus edulis plays an important role among the common amphiboreal species within the parallel communities in question (Fucus evanescens from the northern Pacific and F. distichus from the Murman coast, northern Atlantic Ocean).

Non-vicarious species are remarkably more numerous in the Northern Pacific than in the Atlantic Ocean (respectively 42 to $60 \%$ and $17.8 \%$ of the total number of species in the community); their contribution to the total biomass is of almost no significance in both cases (not above $6 \%$ ).

\section{Convergent or isomorphic communities}

Convergent or isomorphic communities contain groups of organisms which inhabit more or less similar facies of the intertidal zone all around the world; they are dominated by species, not closely related but belonging to the same life form. A series of formations composed mainly of isomorphic communities can be united in a class of formations, or a biome. 


\section{Functionally analogous, or anisomorphic communities}

Dominant species of functionally analogous or anisomorphic communities inhabiting the same system are not related; they belong to different life forms, yet they are members of the same trophic group. Thus, in some places, common intertidal communities with dominating filter-feeders (e.g. barnacles or mytilids) are replaced by communities with other filter-feeders (e. g. sponges, simple ascidian Pyuridae, compound ascidian Polyclinidae, tube worms of the family Sabellidae). On muddy sands or sometimes on rocks, associations of seaweeds are replaced by seagrasses (Phyllospadix or Zostera).

Stephenson \& Stephenson (1972) considered coral reefs in the tropics and dense growths of laminarians in cold and temperate waters to be comparable in their importance, although in the first case, the main producers are by no means the dominating corals themselves but symbiotic algae.

Unfortunately, thus far, we have no data concerning comparisons of the species composition of isomorphic and anisomorphic communities.

In summary, I would like to emphasize that intertidal communities, together with their abiotic environment, should by no means be interpreted as independent ecosystems. The types of intertidal communities discussed above are only components of ecosystems of estuaries, lagoons, bays or the open seashore. This is confirmed partly by the fact that filter-feeders constituting most of the total faunal biomass in many communities of the eulittoral and infralittoral system $(60$ to $95 \%$ ), feed on pelagic forms, although there are also many macrophytes available which could be regarded as a potential food sources (Kussakin, 1963). This fact appears to exclude the possibility to consider the systems concerned as closed and self-contained entities, such as an ecosystem should be.

\section{LITERATURE CIT'ED}

Allee, W. C., 1923. Studies in marine ecology. 4. The effect of temperature in limiting the geographical range of invertebrates of the Woods Hole littoral. Ecology 4, 341-354.

Appellöff, A., 1912. Invertebrate bottom fauna of the Norwegian Sea and North Atlantic. In: Murray, J. \& Hjort, J.: The depths of the ocean, Macmillan, London, 457-560.

Beauchamp, P. de, 1914. Les grèves de Roscoff. Etude sur le répartition des êtres dans la zone des marées. Paris.

Dellow, V., 1950. Intertidal ecology at Narrow Neck Beef, N. Z. Pacif. Sci. 4, 355-374.

Derjugin, K. M., 1915. Fauna of the Kola Bay and the condition of its existence. Mem. Imp. Acad. Sci., phys. math. Dep. (Ser. 8) 34, 1-929.

Feldmann, J., 1951. Ecology of marine algae. In: Manual of phycology, Ed. by G. Smith. Ronald, New York, 313-334.

Gurjanova, E. F., 1961. Comparative research biology of the littoral in the far eastern Seas. Proc. 9th Pacif. Sci. Congr, 19, 75-86.

- \& Ushakov, P. V., 1928. On the fauna of Black Bay (Novaya Zemlya). Explors Seas USSR 6, 5-72. (Russ.).

- 1929. The littoral of East Murman. Explors Seas USSR 10, 5-40 (Russ.). 
- Zachs, I. \& Ushakov, P., 1928. Das Littoral des Kola-Fjords. T. 1. Trudy leningr. Obshch. Estest. 58 (Livr. 2), 89-143 (Russ.).

- - 1929. Das Littoral des Kola-Fjords. T. 2. Trudy leningr. Obshch. Estest. 59 (Livr. 2), $47-152$ (Russ.).

- - 1930a. Das Littoral des Kola-Fjords. T. 3. Trudy leningr. Obshch. Estest. 60 (Livr. 2), 17-107 (Russ.).

- - - $1930 \mathrm{~b}$. The littoral of West Murman. Explors Seas USSR 11, 47-104.

Hutchins, L. W., 1947. The bases for temperature zonation in geographical distribution. Ecol. Monogr. 17, 325-335.

Kussakin, O. G., 1958. Intertidal zone of the southern Kurile Islands, its fauna and flora. M. S. Thesis, Leningrad Univ., 20 pp. (Russ.).

- 1961. Certain peculiarities of the fauna and flora distribution on the intertidal zone of the South Kurile Islands. Explors Far-Eastern Seas USSR 7, 312-343 (Russ.).

- 1963. On the quantitative characteristics of flora and fauna in the intertidal zone of the Barents Sea islands of the Kandalaksha State Preserve. Trudy Kandalakshskogo Gos. Zapov. 3, 183-223 (Russ.).

- 1975. A list of macrofauna in the intertidal zone of the Kurile Islands, with remarks on zoogeographical structure of the region. Publs Seto mar. biol. Lab. 22, 47-74.

- 1976. Biogeographical structure of the intertidal fauna of Kurile Islands and Role of summer water temperature in its formation. Biol. Morja 2, 31-34 (Russ.).

- Kudryashov, V. A., Tarakanova, T. F. \& Shornikov, E. U., 1974. The belt forming florafauna communities from the intertidal zone of the Kurile Islands. In: Flora and fauna of the intertidal zone of the Kurile Islands. Nauka, Novosibirsk, 339-372 (Russ.).

Mokievskij, O. B., 1949. Freshwater intertidal zone of the estuary of Amur. Rep. Acad. Sci. USSR 66, 1187-1190 (Russ.).

- 1953. On the fauna of the littoral of the Okhotsk sea. Trudy Inst. Okeanol. 7, 167-197 (Russ.).

- 1956. Some specific traits of the littoral fauna of the continental coast of the Japan Sea. Trans. Conf. Probl. Themes zool. Inst. Leningrad 6, 116-121 (Russ.)

- 1960. The intertidal fauna of north-western coast of the Sea of Japan. Trudy Inst. okeanol. 34, 242-328.

Orton, J. H., 1920. Sea temperature, breeding and distribution in marine animals. J. mar. biol. Ass. U. K. 12, 339-366.

Spassky, N. N., 1961. The intertidal zone of the south-east shore of Kamshatka. Explors. Far-Eastern Seas USSR 7, 261-311 (Russ.).

Stephenson, T. A. \& Stephenson, A., 1972. Life between tidemarks on rocky shores. Freeman, San Francisco, 426 pp.

Ushakov, P. V., 1951. Intertidal zone of Okhotsk Sea. Rep. Acad. Sci. USSR 76, 127-130 (Russ.).

Vaillant, L., 1891. Nouvelles études sur les zones littorales. Annls. Sci. nat. (Zool) 12, 39-50.

Zachs, I. G., 1927. Preliminary data on the distribution of fauna and flora in the incoast zone of the Bay of Peter the Great (the Sea of Japan). Proc. 1st Conf. Stud. productive Forces Far East, 4, 213-248 (Russ.).

- 1929. On the knowledge of benthic communities in the Sea of Shantar. Izv. tikhookean. nauchn.-promysl. Sta. 3, 1-98 (Russ.).

Author's address: Prof. O, G. Kussakin

Institute of Marine Biology

Vladivostok 690022

USSR 